\title{
Development and Innovation of College Students' Core Value Education since Reform and Opening up
}

\author{
Qingming You ${ }^{1, a^{*}}$ and Dan Xie ${ }^{1, b}$ \\ ${ }^{1}$ Nanchang Institute of Science \& Technology, China \\ ayouqingming667@sina.com
}

Keywords: Reform and opening up; College students; Core value education

\begin{abstract}
Values of college students not only have decisive role on own development, but also are related to success of China socialist modernization construction career as well as rise and fall of a nation as hope of national development in the future. College students' core values are regarded as important parts of social core values. Value education on students is important task and historical mission in current ideological and political work in colleges and universities. China social transformation speed is faster since reform and opening up. Market economy shows brand-new development trend. People's ideological concept and lifestyle are profoundly changed. College students' values are also affected by macro-environment at home and abroad. How to innovate education mode and mode of college students' core values has become the top priority currently under such environment. The author regards reform and opening up as research background during the research process in the paper. College students are regarded as research objects. Core values are treated as research contents, dialectical analysis method, comparative analysis method, theory-practice linkage and other methods are adopted for discussion, thereby proposing development strategy.
\end{abstract}

\section{Introduction}

Chinese Communist Party has attached great importance to value education of college students for long term. China market economy development is upgraded to a new level since reform and opening up. Foreign contact is continuously strengthened. However, college students' core values are constantly affected by factors in many aspects. How to innovate college students' core value education has become top priority currently under new situation.

\section{Changes of College Students' Values since Reform and Opening up}

Basic Trend of College Students' Value Change since Reform and Opening up. Diversified trend. Since political, economic, cultural and other fields have been changed greatly after reform and opening up, allocation mode, employment mode, interest relationship and other aspects must undergo unprecedented changes. Corresponding ideological value concepts of people show diversified trend, which objectively affect the values of young college students. 'God would give an important task to a certain person' and 'taking the world as own task' have become ideals and ambition of college students then with continuous deepening of reform and opening up from 1980s to 1990s. Diversified change trend of college students' values is more and more prominent since the 1990s to present. The values are mainly changed to the thought direction of self-pursuit, freedom and equality.

Trend of entirety and individual integration. Values of college students are more inclined to collectivism before reform and opening up. Of course, it has close connection with Chinese national conditions at that time. However, college students focus more on individual prospect and self-development since reform and opening up. Values of 'aiming at individuals subjectively and society objectively' is further promoted on the basis of collectivism. Tight connection between individual value and social value is advocated, thereby striving for creating own happy life. 
Trend of ideal and reality coexistence. College students' ideal faith is still very firm at the beginning of reform and opening up, and college students have infinite longing for socialism and communism society. Many significant events occurred at home and abroad with continuous deepening of reform and opening up especially in the 1990s. They inevitably affected the values of college student population. Some students have confusion psychological state. Students faced more severe employment situation since the beginning of the century. College students are busy with various examinations and textual researches. College students prefer to pursue more realistic personal life ideal compared with those lofty and distant ideals, and they desire for better life.

Main Factors Affecting Changes of College Students' Value since Reform and Opening up. External factors. First of all, social transformation occurs under the precondition of constant socialist system in China from the perspective of social transformation, which is gradually transformed from quantity accumulation to quality transition. There is a dialectical relationship between social change and value change. Both aspects not only interact, but also can affect mutually. College students have active thought as a special social group, who can easily accept new things. Therefore, Changes of each factor in social transformation can produce certain influence on generation of their values. Higher education reform at the end of the last century is adopted as an example. College enrollment system is reformed from national 'full turnkey' to 'double provision' through 'combination' under China macro-policy. In addition, colleges and students are constantly increasing enrollment by current independent admission examination. Chinese higher education is gradually developed from elite education to mass education. Therefore, problem of difficult employment for college students is presented for people. Contemporary college students generally have sense of crisis in employment.

Secondly, market economy itself emphasizes the dominant role of market in allocation of resources from the perspective of market economy. It has principles of freedom, equality, competition, legality, etc., which have certain role for college students to establish positive ideas. Meanwhile, market economy is a double-edged sword, it induces money worship, hedonism, nationalism and extreme individualism, and people are gradually expanded under the interest trend of market economy, phenomenon of mercenary is available, therefore ideological values of college students have some misunderstandings.

Thirdly, China constantly reinforces the linkage since reform and opening up from the perspective of western culture impact, China is further integrated into global trade especially since joint into WTO. In addition, some western developed countries utilize own huge advantages in network for occupying network position and network voice with rapid development of Internet. Western culture and values are vigorously diffused to China, even college students' ideas and values are penetrated in China, therefore contemporary college students have various extreme individualism phenomena in China.

Internal factors. All changes and developments are results of joint effects of internal factors and external factors from the perspective of dialectical materialism. It even can be concluded that internal factor is the root cause of thing change and development. Factors affecting changes of college students' core values include college students' psychological and physiological characteristics, education degree and their own cognition process to society from the perspective of internal factor. China college students' cognitive level is enhanced unceasingly since reform and opening up. It can reflect previous values. In addition, since college students are in the special period of personal physical and mental fast growth, it is also a special period in the life with creativity and vitality. Therefore, there are always certain dynamic change characteristics in the aspect of values. People are easily affected in face of constantly changing external matters since they do not participate in the society, thereby leading to changes of value orientation.

\section{Development Process of College Students' Core Value Education since Reform and Opening up}

College Students' Core Value Education at the Beginning of Reform and Opening up. Main forms of college students' core value education are criticism and reflection at the beginning of reform and opening up. For example, Chinese Communist Party led people across the country to launch a 
nationwide movement of disclosing, criticizing and inspecting Lin Biao and 'Gang of Four' in the period. Then, debate about truth standard was implemented. Contents before reform and opening up was followed to great extent in the aspect of core value education content of college students. Main line of college students' core value education contains Marxism-Leninism, Mao Zedong thought, communist ideal, patriotism and collectivism.

College Students' Core Value Education in the 1980s. Propaganda Department of the CentralCommittee of the CPC put forward 'Opinions on Strengthening Patriotic Propaganda and Education' in 1983. In the opinions, it is proposed that patriotism propaganda and education should be frequently implemented and strengthened during current China socialist modernization construction in China, thereby cultivating patriotic spirit of all people, especially teenagers. Chinese Communist Party had some errors in the aspect of college students' ideological education in the period, but more prominent achievements were obtained in core value education as a whole. Both contents and modes showed some brand-new features. The education teaching contents were more concrete without many voids. The teaching mode also showed diversified features.

College Students' Core Value Education in the 1990s. National environment provided more favorable opportunity for development in China since the 1990s. China gradually entered a brand-new historical stage since reform and opening up. The openness was also growing with continuous deepening of reform. A new ideological liberation movement was launched by a series of important speeches given by leaders. College students' core value education is gradually deepened under the background of establishing socialist market economy as a whole. Compared with the previous stage, college students' core value education stresses wide development of patriotism, collectivism and socialism education in spiritual civilization creation activities in the stage, education contents and modes achieve new breakthrough.

College Students' Core Value Education since the 21st Century. College students' core value education is further developed with new breakthrough after entering the century. Comprehensive national strength is significantly improved. People's standard of living is also improved to a new level. China has been gradually integrated into economic globalization era and networking. College students' core value education occurs under the background of accelerating globalization process since the new century. College students' core value education at the stage is shown in the following figure. Novel Internet and new media technology are further integrated in education mode around implementation of comprehensively forming well-off society.

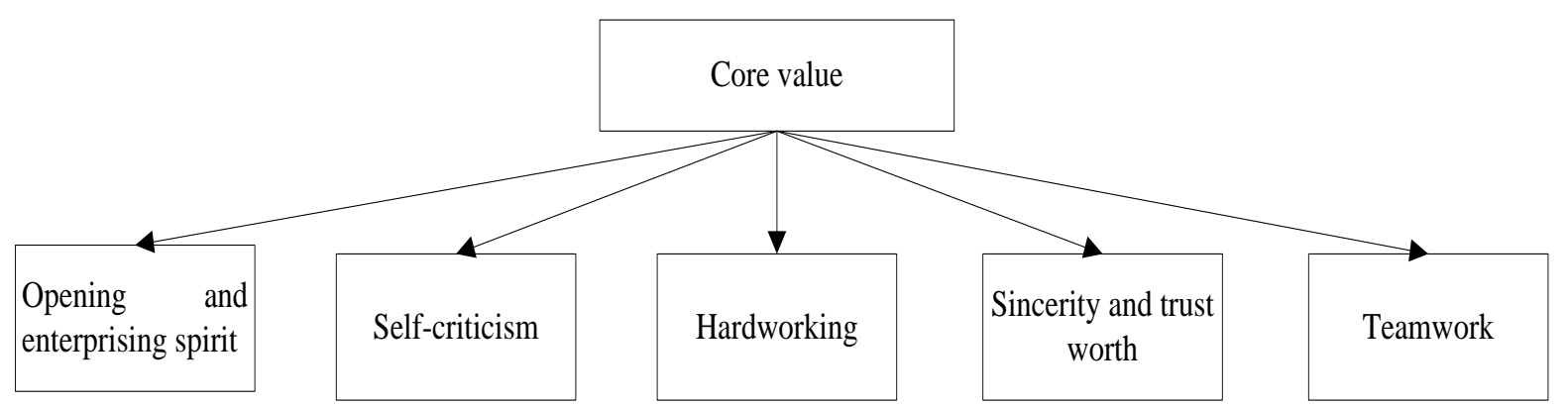

Figure 1. Core value education on contemporary college students

\section{Innovation Strategy of Core Value Education on Contemporary College Students}

Active Refining of Core Values of Contemporary College Students. We can observe that core values of contemporary college students are mainly embodied in four aspects of 'patriotism, ideal, responsibility and innovation' from the perspective of current social development trend and party's guiding principle.

Patriotism: it is required that contemporary college students should have both patriotic emotion and patriotic action. Patriotism refers that the relationship between individual and nation should be properly handled in the new era, and the relationship should be regarded as individual rule, therefore 
realization of individual value can be associated with the fate of the nation. Dedication to 'Chinese dream' of great rejuvenation of Chinese nation should be regarded as own value pursuit.

Ideal: college students always act as successors to socialism career with Chinese characteristics. College students still should make effort to struggle to the common ideal during realization of individual ideal.

Responsibility: the responsibility sense of 'every man has a share of responsibility for the fate of his country' lasts since ancient times. Of course, college students bear different historical responsibilities in different historical periods. Currently, college students bear the responsibility of comprehensively building a well-off society and realizing great rejuvenation of the Chinese nation.

Innovation: dialectical materialism shows that things are changing and developing. Development has the essence of new thing production and existing thin demising. Comrade Jiang Zemin once pointed out that: 'innovation is the soul of progress in one nation, inexhaustible driving force for prosperity of a country, and source of a political party to maintain eternal vitality'. Development of socialism career with Chinese characteristics lies in cultivation of innovative talents, and college students are encouraged to regard innovation as own value goal.

Exertion of Important Role of Ideological and Political Theory Course in Colleges and Universities. Existing condition shows that the achieved effects are different though thought political course has been carried out in a wide range of Chinese colleges and universities. The effects are manifested in insufficient emphasis strength, insufficient education teaching method, etc. In the new stage, people-oriented teaching idea should be established in college ideological and political theory course, and good learning interests of students should be cultivated.

Table 1 Understanding of contemporary students on basic contents of socialism core values

\begin{tabular}{|c|c|}
\hline Whether basic contents of socialism core value is understood or not; & Percentage \\
\hline Very familiar & $9.1 \%$ \\
\hline Basically familiar & $41.3 \%$ \\
\hline Unclear & $30.4 \%$ \\
\hline Basically unfamiliar & $7.8 \%$ \\
\hline Completely unfamiliar & $11.3 \%$ \\
\hline Total & $100 \%$ \\
\hline
\end{tabular}

In addition, ideological and political theory course teachers should have scientific teaching method and good ideological and moral quality. ideological and political theory course teachers should be good at using modern education technology for tightly linking teaching technology with teaching contents with fast development of modern science and technology, thereby enhancing the appeal of education teaching activities, and improving teaching quality and level. It is worth mentioning that it is necessary to establish and perfect scientific ideological and political theory student assessment and evaluation system. In the past, achievements and results are overemphasized in plan evaluation process due to influence of exam-oriented education. Students' cognition and behavior are ignored, thereby seriously hindering student's enthusiasm. Therefore, colleges and universities should establish diversified assessment mode, and gradually make effort to multidirectional and diverse assessment and evaluation.

Active Utilization of New Media Resources. Network changes people's lifestyle, thinking mode and values due to its openness, interactivity and virtual feature since its generation. 
Table 2 Focus on national affairs by comp temporary college students through network

\begin{tabular}{|c|c|}
\hline Whether national affairs are concerned through network or not; & Percentage \\
\hline Frequent & $31 \%$ \\
\hline Occasional & $50.3 \%$ \\
\hline Rare & $17.8 \%$ \\
\hline Total & $100 \%$ \\
\hline
\end{tabular}

Realization of core value education of contemporary college students must depend on support role of novel network technology. Concretely, colleges and universities should strengthen supervision and construction of campus network. In addition, special content and webpage about college students' core value education should be established in school websites in order to meet diversified development demand of students. Favorable modes of college students are adopted for attracting students. It is necessary to comprehend new media technology for most education workers. Education workers can strengthen exchange with students through mail, WeChat, QQ and other network tools under necessary conditions.

Full Exertion of Model Demonstration Force of College Students to Practice Core Values. Lenin once said: 'after the regime is transferred to proletariat, after despoilers are deprived,... own wide influence can be manifested by model power for the first time'. Comrade Deng Xiaoping also repeatedly stressed: 'example is better than precept'. It is perfect explanation on moral model social value. College student group is in a special period of life. The vast majority of college students have their own idols and examples. The force of examples always can promote college students for constant development and progress. Colleges and universities should make use of the psychological characteristic of college students, give full play to opinion guide and public opinion guidance functions of ideological propaganda work. When core values of college students are educated, propaganda and report of advanced characters and advanced deeds of college students to practice core values also can be increased, thereby fully exerting the demonstration force of examples. Core values of college students can be gradually changed into a group consciousness thereof. College students are encouraged to abide by and practice the values consciously.

\section{Conclusion}

In general, core value education of college students will be an eternal topic because it not only is closely related to own future development of college student subjects, but also is tightly linked with construction and development of socialism career with Chinese characteristics. China society was greatly changed since reform and opening up, thereby people's lifestyle gradually showed diversified trend, and values of college students underwent a constantly changing process. Core value education on college students is a complicated and huge systematic project, which involves many factor, forces of the whole society should be mobilized for participation, thereby creating good social environment for core value education of college students.

\section{Acknowledgement}

This research was financially supported by The Project of Jiangxi College Humanities and Social Science Research Institute 2014 Project 'Research on College Students' Core Value Education since Reform and Opening Up' (NO. MSK1440).

\section{References}

[1] You Qingming. Research on college students' core value education since reform and opening up. Guizhou Normal University, 2014. 
[2] Huang Xia. Research on mode innovation of college students' socialist core value education. Chinese Communist Party Liaoning Provincial Party School, 2014.

[3] Meng Xuemei. Guidance of college students' value education by socialist core value system. Science Review, 2014.

[4] Wang Qing. Research on innovation of socialist core value education of college students under network environment. Contemporary Education Practice and Teaching Research, 2015 (10).

[5] Guo Zhaojun. New characteristics and cause perspective of college student values since reform and opening up. Social Sciences Review, 2012 (9): 17-19. 